\title{
XRCC1 Arg399Gln was associated with repair capacity for DNA damage induced by occupational chromium exposure
}

\author{
Xuhui Zhang ${ }^{1,2+}$, Xuan Zhang ${ }^{1,3+}$, Lei Zhang ${ }^{2}$, Qing Chen ${ }^{3}$, Zhangping Yang ${ }^{2}$, Jingmin $\mathrm{Yu}^{4}$,
} Hong $\mathrm{Fu}^{5}$ and Yimin $\mathrm{Zhu}^{1 *}$

\begin{abstract}
Background: Occupational chromium exposure may induce DNA damage and lead to lung cancer and other work-related diseases. DNA repair gene polymorphisms, which may alter the efficiency of DNA repair, thus may contribute to genetic susceptibility of DNA damage. The aim of this study was to test the hypothesis that the genetic variations of 9 major DNA repair genes could modulate the hexavalent chromium ( $\mathrm{Cr}(\mathrm{VI})$ )-induced DNA damage.

Findings: The median $\left(\mathrm{P}_{25}-\mathrm{P}_{75}\right)$ of Olive tail moment was 0.93 (0.58-1.79) for individuals carrying $\mathrm{GG}$ genotype of XRCC1 Arg399GIn (G/A), 0.73 (0.46-1.35) for GA heterozygote and $0.50(0.43-0.93)$ for AA genotype. Significant difference was found among the subjects with three different genotypes $(P=0.048)$ after adjusting the confounding factors. The median of Olive tail moment of the subjects carrying A allele (the genotypes of AA and GA) was 0.66 (0.44-1.31), which was significantly lower than that of subjects with $G G$ genotype $(P=0.043)$. The A allele conferred a significantly reduced risk of DNA damage with the OR of 0.39 ( $95 \% \mathrm{Cl}: 0.15-0.99, P=0.048)$. No significant association was found between the XRCC1Arg194Trp, ERCC1 C8092A, ERCC5 His1104Asp, ERCC6 Gly399Asp, GSTP1 Ile105Val, OGG1 Ser326Cys, XPC Lys939GIn, XPD Lys751GIn and DNA damage.
\end{abstract}

Conclusion: The polymorphism of Arg399GIn in XRCC1 was associated with the Cr (VI)- induced DNA damage. XRCC1 Arg399GIn may serve as a genetic biomarker of susceptibility for $\mathrm{Cr}$ (VI)- induced DNA damage.

Keywords: DNA damage, Genetic susceptibility, XRCC1, Occupational chromium exposure

\section{Findings}

\section{Background}

Chromium compounds are widely used in industry as chromium compound manufacturing, electroplating, leather tanning, welding, corrosion inhibitors, and alloying metal, etc. The respiratory tract is the major way of occupational exposure to chromium besides oral and dermal exposure. Trivalent chromium( $\mathrm{Cr}(\mathrm{III}))$ compound, an essential micronutrient, has been considered to be lower toxicity [1]. Previous studies [2-6] have revealed that hexavalent chromium $(\mathrm{Cr}(\mathrm{VI}))$ compounds could

\footnotetext{
* Correspondence: zhuym@zju.edu.cn

${ }^{\dagger}$ Equal contributors

'Department of Epidemiology and Biostatistics, Zhejiang University School of Medicine, 388 Yu-Hang-Tang Road, Hangzhou 310058, Zhejiang, People's Republic of China

Full list of author information is available at the end of the article
}

induce DNA damage. Exposure to $\mathrm{Cr}(\mathrm{VI})$ significantly increases the risk of respiratory tract cancer [7,8], thus $\mathrm{Cr}(\mathrm{VI})$ has been classified as a human carcinogen (group 1) by the International Agency for the Research on Cancer (IARC) [9].

Although the mechanisms involved in $\mathrm{Cr}(\mathrm{VI})$ induced damage remains to be fully elucidated, generation of reactive oxygen species (ROS) was likely the key step in the intracellular reduction of $\mathrm{Cr}(\mathrm{VI})$ by cellular reductant such as reduced glutathione (GSH) and ascorbic acid. The excessive production of ROS may lead to oxidative stress, DNA damage $[4,10]$. Common forms of DNA damage include DNA strand breaks, chromiumDNA adducts, cross-links and oxidative DNA damage [2-4,11]. However, induced DNA damage could be repaired through individual repair system to maintain

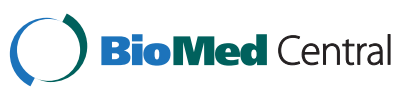


the genomic stability. The common mechanisms of DNA repair include base excision repair (BER), nucleotide excision repair (NER), mismatch repair, etc. Therefore, the residue DNA damage, which associates with the risk of lung cancer and other diseases, is dependent on capability of DNA repair. High inter- individual variation of DNA damage had been found in the previous studies on chromium exposure [2,12]. Therefore, the individual DNA repair capacity might modulate the DNA damage and associate with the risk of involved diseases under chromium exposure. DNA repair gene polymorphisms, which may alter the efficiency of DNA repair, contribute to genetic susceptibility of DNA damage. Hence, we hypothesize that the genetic variation of 9 major DNA repair genes could modulated the $\mathrm{Cr}(\mathrm{VI})$ - induced damage and might serve as the genetic biomarkers of susceptibility.

To examine this hypothesis, we recruited 157 chromiumexposed electroplating workers and 93 control subjects. DNA damage in peripheral lymphocytes was evaluated with alkaline comet assay. Nine polymorphisms of DNA repair genes XRCC1 Arg399Gln, XRCC1Arg194Trp, ERCC1 C8092A, ERCC5 His1104Asp, ERCC6 Gly399Asp, GSTP1Ile105Val, OGG1 Ser326Cys, XPC Lys939Gln, XPD Lys751Gln were determined. The associations between these polymorphism markers and the $\mathrm{Cr}$ (VI)- induced DNA damage were analyzed.

\section{Materials and Methods Study subjects}

157 electroplating workers were recruited from 20 electroplating factories in Hangzhou, China from 20092010. Control subjects $(n=93)$ were recruited from the workers without exposure to chromium compounds and other known physical or chemical genotoxic agents. Subjects with abnormal liver or kidney function and suffering from other chronic diseases such as cancers, diabetes, heart diseases were excluded in the study. All the subjects were interviewed for information of age, smoking habits, alcohol consumption, medical history and years of chromium exposure. Short- term sampling of air was conducted according to Specifications of Air Sampling for Hazardous Substances Monitoring in the Workplace in China (GBZ159-2004). Airborne chromium concentration was measured by graphite furnace atomic absorption spectrophotometer (M6 Thermo, USA). About $4 \mathrm{ml}$ of peripheral vein blood sample was collected from each subject and drawn into two vacuum tubes containing $3.6 \mathrm{mg}$ of EDTA. $2 \mathrm{ml}$ of blood was stored at $4^{\circ} \mathrm{C}$ for determining chromium levels and the comet assay, and the other was stored at $-80^{\circ} \mathrm{C}$ for DNA isolation and genotyping. The study protocol was approved by the Institutional Review Board of Hangzhou
Center for Disease Control and Prevention. Written informed consent was obtained from each subject.

\section{DNA damage determination}

The alkaline comet assay was employed to detect the DNA damage in peripheral lymphocytes. The alkaline comet assay was performed as previously described with some modifications [13]. Peripheral blood $(10 \mu \mathrm{l})$ was mixed with 75 ul of $0.75 \%$ low-melting- point agarose and transferred to a microscope slide pre-coated with a layer of $0.75 \%$ normal-melting-point agarose. The slides were immersed in the lysis buffer $(2.5 \mathrm{~mol} / \mathrm{L} \mathrm{NaCl}$, $100 \mathrm{mmol} / \mathrm{L}$ EDTA, $10 \mathrm{mmol} / \mathrm{L}$ Tris, freshly added 1\% Triton $\mathrm{X}-100$ and $10 \%$ DMSO, $\mathrm{pH} 10$ ) for $1 \mathrm{~h}$ at $4^{\circ} \mathrm{C}$ to remove proteins. The slides were then placed in a horizontal electrophoresis tank containing electrophoresis buffer (300 mmol/L NaOH, $1 \mathrm{mmol} / \mathrm{L}$ EDTA, pH 13) for $20 \mathrm{~min}$ to allow DNA unwinding. The electrophoresis was carried out in the same buffer for $20 \mathrm{~min}$. After electrophoresis, the slides were neutralized in the neutralization buffer $(0.4 \mathrm{~mol} / \mathrm{L}$ Tris, $\mathrm{pH} 7.5)$, and then stained with $50 \mu \mathrm{L}$ ethidium bromide solution $(20 \mu \mathrm{g} / \mathrm{mL})$. All the steps were conducted under yellow light to prevent additional DNA damage. One hundred nuclei were selected randomly from each sample. The observation was made at $400 \times$ magnification using a fluorescence microscope (DMI 4000) equipped with a 530-nm excitation filter and a computer-based image analysis program CASP. The medians of Olive tail moment, tail length and tail DNA\% were used for assessing DNA damage. Olive tail moment is defined as the product of the tail length and the fraction of total DNA in the tail and calculated as [(tail mean - head mean $) \times($ tail DNA\%/100)] [13].

\section{Genotyping}

DNA was extracted from peripheral lymphocytes using genomic DNA extraction kits (Tiangen blood genomic DNA extraction kits, Tiangen, China). The genotypes of XRCC1 Arg194Trp and Arg399Gln were determined with PCR-RFLP. The primers of amplification were as follows: XRCC1 Arg194Trp:F: 5'-GCC CCG TCC CAG GTA-3',R: 5'-AGC CCC AAG ACC CTT TCA CT3';XRCC1 Arg399Gln:F: 5' -TTG TGC TTT CTC TGT GTC CA-3',R: 5' -TCC TCC AGC CTT TTC TGA TA3'. PCR for XRCC1 Arg194Trp and XRCC1 Arg399Gln were performed under the following conditions: $95^{\circ} \mathrm{C}$ for $5 \mathrm{~min}$, followed by 30 cycles of $94^{\circ} \mathrm{C}$ for $40 \mathrm{~s}, 56^{\circ} \mathrm{C}$ (Arg399Gln) or $61^{\circ} \mathrm{C}$ (Arg194Trp) for $30 \mathrm{~s}$ and $72^{\circ} \mathrm{C}$ for $30 \mathrm{~s}$ and a final elongation step at $72^{\circ} \mathrm{C}$ for $10 \mathrm{~min}$. Then the PCR products were digested at $37^{\circ} \mathrm{C}$ for $12 \mathrm{~h}$ with restricted endonucleases MspI (NEB, USA) (Arg399Gln) or PvuII (Arg194Trp). The $10 \mu \mathrm{L}$ of digested PCR products were electrophoresed on a $2 \%$ agarose gel. For 
Arg399Gln, one band of 615 bp represents gln/gln, two bands (375 bp and $240 \mathrm{bp}$ ) represent arg/arg, and three bands (615 bp, $375 \mathrm{bp}$ and $240 \mathrm{bp}$ ) represent arg/gln. For Arg194Trp, one band of 491 bp represents arg/arg, two bands (197 bp and $294 \mathrm{bp}$ ) represent trp/trp, and three bands (197 bp, 294 bp and 491 bp) represent arg/gln. The genotypes of ERCC1 C8092A, ERCC5 His1104Asp, ERCC6 Gly399Asp, GSTP1Ile105Val, OGG1 Ser326Cys, XPC Lys939Gln, XPD Lys751Gln were detected using TaqMan probe- based real time PCR (7900, ABI, USA). The primer and probe sequences were obtained from the National Cancer Institute's SNP500Cancer database. Negative controls and previously genotyped samples were included in each plate to ensure the accuracy of the genotyping.

\section{Statistical analysis}

Because distribution of DNA damage data (olive tail moment, tail length and tail DNA\%) do not follow normal distribution, the median and $\mathrm{P}_{25}-\mathrm{P}_{75}$ was used to summarize the central location and variation of data, and compared among genotype groups using nonparametric test (Kruskal-Wallis test). Chi square test was used to compare frequency data. A goodness-of-fit Chi square test was used to evaluate for the Hardy-Weinberg equilibrium. Multivariate linear (the DNA damage data was square root-transformed) and logistic models were used to adjust the potential confounding variables including age, gender, smoking status, drinking and occupational exposure time of chromium. A two-sided $P$ value of less than 0.05 was considered statistically significant. All statistical calculations were performed by using SPSS 16.0.

\section{Results}

\section{Characteristics of the study population}

The mean age ( \pm standard deviation) of exposed subjects was $39.7 \pm 8.3$ years while $38.8 \pm 9.6$ years for control group $(P>0.05)$. There were no significant differences in gender, smoking status, alcohol consumption between the two groups (all $P$ values $>0.05$ ). The median time of chromium exposure was 5.3 years (range: 0.5 to 23 years).
The median of short-term exposure concentration of chromium in the air at the 20 electroplating workplaces was $0.060 \mathrm{mg} / \mathrm{m}^{3}$ (range from 0.016 to $0.531 \mathrm{mg} / \mathrm{m}^{3}$ ), which was higher than the permissible concentration short term exposure limit (PC-STEL) of chromium in China $\left(0.05 \mathrm{mg} / \mathrm{m}^{3}\right)$, and $52 \%$ factories had chromium level above the standard of PC-STEL.

\section{The chromium concentration in erythrocytes and DNA damage in exposed and control subjects}

Chromium concentrations in erythrocytes and DNA damage in exposed and control groups were shown in Table 1 . The exposed subjects had the median $\left(\mathrm{P}_{25}-\mathrm{P}_{75}\right)$ of chromium concentration in erythrocytes of $4.41 \mu \mathrm{g} / \mathrm{l}$ $(2.50,5.29)$, which was about two times higher than that in control subjects $(1.54 \mu \mathrm{g} / \mathrm{l}(0.61-2.98), P<0.001)$. The medians of Olive tail moment, tail length and tail DNA\% in exposed group were 1.13(0.47-1.45), 11.77 (6.42-14.84) and 3.69 (2.50-5.29), respectively, and were significantly higher than those in control subjects $(0.12$ $(0.04-0.22), \quad 3.26 \quad(3.00-4.00)$ and 0.59 (0.19-1.11) $(P<0.001)$.

\section{Genotypes of the polymorphism of XRCC1 Arg399GIn and} the DNA damage induced by $\mathrm{Cr}(\mathrm{VI})$ exposure

The allele frequencies for XRCC1 399Gln, XRCC1 194Trp, OGG1 326Cys, ERCC1 8092A, ERCC5 1104Asp, ERCC6 399Asp, XPD 751Gln, XPC 939Gln, GSTP1105Val were 0.24, 0.24, 0.54, 0.57, 0.49, 0.46, 0.08, $0.38,0.16$, respectively. Genotype distributions of all the polymorphisms studied were all consistent with HardyWeinberg equilibrium $(P>0.05)$. The medians and $\mathrm{P}_{25^{-}}$ $\mathrm{P}_{75}$ of Olive tail moment, tail length and tail DNA\% in the subjects with different genotypes were shown in Table 2.

The median of Olive tail moment $\left(\mathrm{P}_{25}-\mathrm{P}_{75}\right)$ was 0.93 (0.58-1.79) for individuals carrying GG genotype of XRCC1 Arg399Gln (G/A), 0.73 (0.46-1.35) for GA heterozygote and $0.50(0.43-0.93)$ for AA genotype, respectively. After adjusting the confounding factors of gender, smoking status, drinking and occupational exposure time of chromium, significant difference in Olive tail moment was found among the subjects with different genotypes $(P=0.048)$. The median of Olive tail moment of the

Table 1 The chromium concentration in erythrocytes $(\mu \mathrm{g} / \mathrm{l})$ and DNA damage in exposed and control subjects

\begin{tabular}{llll}
\hline & Exposed subjects $\mathbf{n}=\mathbf{1 4 9}$ & Control subjects $\mathbf{n}=\mathbf{7 7}$ & $\boldsymbol{P}_{\text {value }}$ \\
\hline chromium concentration in erythrocytes $(\mu \mathrm{g} / \mathrm{l})$ & $4.41(2.50-5.29)$ & $1.54(0.61-2.98)$ & $<0.001$ \\
Olive tail moment & $1.13(0.47-1.45)$ & $0.12(0.04-0.22)$ & $<0.001$ \\
Tail Length & $11.77(6.42-14.84)$ & $3.26(3.00-4.00)$ & $<0.001$ \\
Tail DNA\% & $3.69(2.50-5.29)$ & $0.59(0.19-1.11)$ & $<0.001$
\end{tabular}

1. Data were presented as median $\left(\mathrm{P}_{25}-\mathrm{P}_{75}\right)$.

2. $P$ values were calculated with rank sum test between the exposed and control subjects.

3. Owing to missing detect in DNA damage and genotype, the numbers of subjects in Table 2 were less 157 in exposed group and 93 in control group. 
Table 2 DNA damage in the exposed subjects with different genotypes of polymorphisms

\begin{tabular}{|c|c|c|c|c|c|c|c|c|}
\hline \multirow[t]{2}{*}{ SNP } & \multirow[t]{2}{*}{ genotype } & \multirow[t]{2}{*}{$\mathrm{n}$} & \multicolumn{2}{|c|}{ Olive tail moment } & \multicolumn{2}{|c|}{ Tail length } & \multicolumn{2}{|c|}{ Tail DNA\% } \\
\hline & & & Median & $P_{25}-P_{75}$ & Median & $P_{25}-P_{75}$ & Median & $P_{25}-P_{75}$ \\
\hline \multirow[t]{6}{*}{ XRCC1 Arg399GIn } & GG & 70 & 0.93 & $0.58-1.79$ & 9.74 & $6.89-18.14$ & 3.25 & $1.94-5.58$ \\
\hline & GA & 42 & 0.73 & $0.46-1.35$ & 8.19 & 5.93-13.79 & 2.50 & $1.77-4.36$ \\
\hline & AA & 8 & 0.50 & $0.43-0.93$ & 6.64 & $5.00-9.92$ & 1.91 & $1.43-3.03$ \\
\hline & $P^{*}$ & & 0.048 & & 0.050 & & 0.039 & \\
\hline & $A A+G A$ & 50 & 0.66 & $0.44-1.31$ & 8.00 & $5.69-13.74$ & 2.32 & $1.66-4.33$ \\
\hline & $p^{f}$ & & 0.043 & & 0.067 & & 0.046 & \\
\hline \multirow[t]{4}{*}{ XRCC1 Arg194Trp } & CC & 66 & 0.75 & $0.47-1.45$ & 8.55 & $6.30-14.22$ & 2.82 & $1.66-4.85$ \\
\hline & $\mathrm{CT}$ & 49 & 0.91 & $0.48-1.49$ & 9.69 & $6.97-16.25$ & 3.22 & $1.83-4.75$ \\
\hline & $\pi$ & 5 & 0.66 & $0.37-1.82$ & 7.67 & $5.11-16.94$ & 2.39 & $1.29-5.84$ \\
\hline & $P^{*}$ & & 0.973 & & 0.964 & & 0.992 & \\
\hline \multirow[t]{4}{*}{ OGG1 Ser326Cys } & CC & 18 & 1.09 & $0.41-1.84$ & 11.72 & $4.92-18.87$ & 3.63 & $1.55-5.80$ \\
\hline & CG & 56 & 0.86 & $0.47-1.46$ & 9.18 & $6.50-15.53$ & 3.07 & $1.73-4.86$ \\
\hline & GG & 41 & 0.78 & $0.56-1.19$ & 8.93 & $6.87-12.07$ & 2.69 & $2.02-4.15$ \\
\hline & $P^{*}$ & & 0.462 & & 0.335 & & 0.377 & \\
\hline \multirow[t]{4}{*}{ ERCC1 C8092A } & $\mathrm{CC}$ & 20 & 0.84 & $0.45-1.38$ & 9.79 & $6.56-15.53$ & 3.20 & $1.77-4.72$ \\
\hline & CA & 47 & 0.71 & $0.47-1.43$ & 8.10 & $5.81-14.10$ & 2.45 & $1.61-4.53$ \\
\hline & AA & 49 & 0.92 & $0.62-1.60$ & 9.66 & $7.21-17.29$ & 3.22 & $2.06-5.50$ \\
\hline & $P^{*}$ & & 0.543 & & 0.690 & & 0.595 & \\
\hline \multirow[t]{4}{*}{ ERCC5 His1 104Asp } & GG & 25 & 0.92 & $0.62-1.60$ & 9.66 & $7.21-17.29$ & 3.22 & $2.06-5.50$ \\
\hline & GC & 61 & 0.84 & $0.54-1.50$ & 9.66 & $6.79-15.88$ & 2.84 & $1.99-4.99$ \\
\hline & CC & 30 & 0.83 & $0.50-1.38$ & 9.21 & $7.01-15.05$ & 3.04 & $1.81-4.59$ \\
\hline & $P^{*}$ & & 0.886 & & 0.931 & & 0.920 & \\
\hline \multirow[t]{4}{*}{ ERCC6 Gly399Asp } & CC & 32 & 0.83 & $0.49-1.14$ & 8.90 & $6.82-11.70$ & 3.03 & $1.87-3.97$ \\
\hline & $C T$ & 54 & 0.75 & $0.48-1.73$ & 8.26 & $6.42-16.12$ & 2.75 & $1.85-5.51$ \\
\hline & $\pi$ & 31 & 1.03 & $0.48-1.57$ & 10.70 & $5.72-18.10$ & 3.22 & $1.68-5.19$ \\
\hline & $P^{*}$ & & 0.143 & & 0.152 & & 0.203 & \\
\hline \multirow[t]{4}{*}{ XPD Lys751Gln } & AA & 94 & 0.82 & $0.48-1.45$ & 9.50 & $6.42-14.84$ & 2.94 & $1.81-4.80$ \\
\hline & $A C$ & 20 & 0.81 & $0.48-1.81$ & 8.79 & $7.00-16.74$ & 2.88 & $1.88-5.81$ \\
\hline & CC & 0 & & & & & & \\
\hline & $P^{*}$ & & 0.771 & & 0.742 & & 0.900 & \\
\hline \multirow[t]{4}{*}{ XPC Lys939GIn } & GG & 45 & 0.89 & $0.56-1.52$ & 9.66 & $6.97-15.96$ & 2.96 & $2.02-5.14$ \\
\hline & GT & 53 & 0.83 & $0.47-1.40$ & 8.87 & $6.63-14.07$ & 2.75 & $1.39-6.13$ \\
\hline & $\Pi$ & 18 & 0.81 & $0.39-2.10$ & 9.13 & $5.68-23.00$ & 2.92 & $1.73-4.57$ \\
\hline & $P^{*}$ & & 0.564 & & 0.379 & & 0.705 & \\
\hline \multirow[t]{4}{*}{ GSTP1 Ile105Val } & AA & 80 & 0.83 & $0.52-1.58$ & 9.21 & $6.75-15.65$ & 2.94 & $1.85-5.30$ \\
\hline & $A G$ & 30 & 0.70 & $0.38-1.41$ & 8.03 & $5.71-15.29$ & 2.41 & $1.62-4.53$ \\
\hline & GG & 6 & 1.02 & $0.71-1.84$ & 11.89 & 8.83-18.95 & 3.74 & $2.46-5.83$ \\
\hline & $P^{*}$ & & 0.169 & & 0.514 & & 0.463 & \\
\hline
\end{tabular}

* The DNA damage data was square root-transformed and multivariable linear model was used after adjusting confounding factors of gender, age, smoking status, drinking and exposure time of chromium.

Comparing the subjects with GG genotype with $A A+G A$.

$\int$ Owing to missing detect in DNA damage and genotype, the numbers of subjects in Table 2 were less 157 in exposed group. 
subjects carrying A allele (the genotypes of AA and GA) was $0.66(0.44-1.31)$, which was significantly lower than that for those with GG genotype ( $P=0.043)$.

Similar results were observed for tail length and tail DNA\% in different groups. After adjustment of the potential confounding factors, significant differences were found in tail length $(P=0.050)$ and tail DNA\% $(P=0.039)$ among different genotypes. The medians of tail length were 9.74 (6.89-18.14) for individuals carrying GG genotype in XRCC1 Arg399Gln (G/A), 8.19 (5.93-13.79) for GA heterozygote and 6.64 (5.00-9.92) for AA genotype, respectively. The medians of tail DNA $\%$ were 3.25 (1.94-5.58) for individuals carrying GG genotype of XRCC1 Arg399Gln (G/A), 2.50 (1.77-4.36) for GA heterozygote and 1.91 (1.43-3.03) for AA genotype, respectively. The median of tail DNA\% of the subjects with carrying $\mathrm{A}$ allele (the genotypes of $\mathrm{AA}$ and GA) was 2.32 (1.66-4.33), which was significantly lower than that for those with GG genotype $(P=0.046)$. A borderline statistical difference was found in tail length when compared the subjects carrying A allele with GG genotype $(P=0.067)$.

No statistical association in Olive tail moment, tail length and tail DNA\% was found among different genotypes of XRCC1 Arg194Trp, ERCC1 C8092A, ERCC5 His1104Asp, ERCC6 Gly399Asp, GSTP1 Ile105Val, OGG1 Ser326Cys, XPC Lys939Gln, XPD Lys751Gln (all the $P$ value $>0.05$ ).

With the 75th percentile of Olive tail moment (1.44) as a cut-off point, the subjects were divided into two groups: high DNA damage $(>1.44)$ and low DNA damage $(\leqq 1.44)$. $31.4 \%(22 / 70)$ of the subjects carrying GG genotype of XRCC1 Arg399Gln (G/A) had higher DNA damage ( $>1.44$ of olive tail moment) while only $16.0 \%$ $(8 / 50)$ in the subjects carrying A allele. Dose- response relationship was found between the number of A allele and DNA damage $\left(P_{\text {trend adjusted }}=0.031\right)$. Comparing with the subjects with genotypes of GG, the subject carrying A allele was significantly associated with the reduced risk of DNA damage with the odds ratio of 0.388 (95\% CI: $0.152-0.992, P=0.048$ ) after adjusting the potential confounders of gender, smoking status, drinking and exposure time of chromium (Figure 1).

\section{Discussion}

In the present study, we found the chromium concentration in erythrocytes was found to be significantly higher in electroplating workers $(4.41 \mu \mathrm{g} / \mathrm{l})$ than that in control subjects. The finding indicated there was hexavalent chromium exposure in electroplating workplace. Occupational chromium exposure in electroplating induced DNA damage. We also found that the polymorphisms of XRCC1 Arg399Gln was associated with $\mathrm{Cr}(\mathrm{VI})$ - induced DNA damage. Our findings supported the hypothesis that the

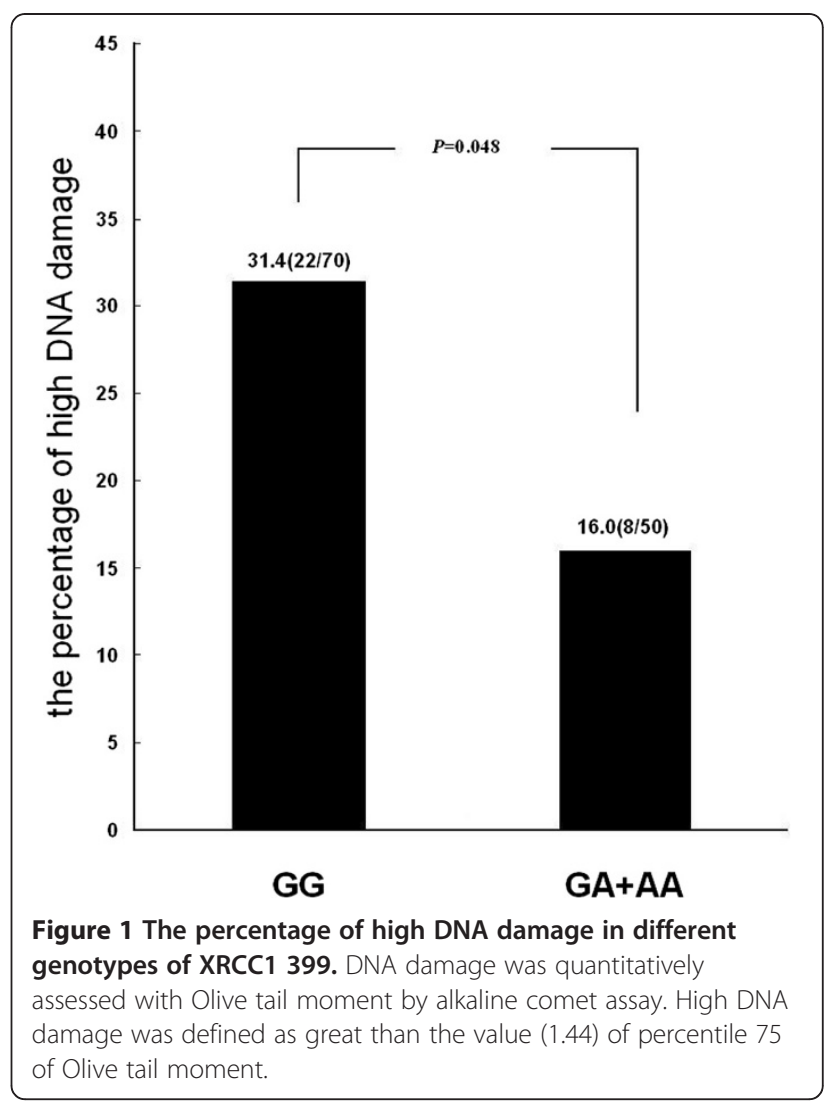

genetic variation of major DNA repair genes could modulate the $\mathrm{Cr}(\mathrm{VI})$ - induced damage. The DNA repair capacity may associate with the risk of chromium exposure induced disease such as lung cancer and XRCC1 Arg399Gln could be served as a genetic biomarker of susceptibility for chromium exposure.

$\mathrm{Cr}$ (VI) compound can actively enter into the cells through the isoelectric and isostructural anion channels [5], phagocytosis [14], et al. Once inside the cell and in the presence of cellular reductants, such as ascorbate and thiols, $\mathrm{Cr}$ (VI) compounds can be reduced through short-lived $\mathrm{Cr}$ intermediates $(\mathrm{Cr}(\mathrm{V})$ and $\mathrm{Cr}(\mathrm{IV}))$ to the stable trivalent state $\mathrm{Cr}$ (III) [15]. During these reactive processes, reactive oxygen species (ROS) such as hydroxyl radicals, single oxygen, superoxide and hydrogen peroxide, were generated. The resulting excessive production of ROS may lead to oxidative damage, DNA adducts and crosslinks $[16,17]$. Iarmarcovai et al. [18]. found the binucleated micro-nucleated cell rate in chromium-exposed welding worker was significantly higher than in control subjects. In the previous study [2], we found the $\mathrm{Cr}$ (VI) exposed electroplating workers had higher concentrations of 8-OHdG (an indicator of oxidative DNA damage), olive tail moment, tail length and tail DNA\% which were evaluated by comet assay. These 
findings were in agreement of the other previous studies $[3,19]$. Therefore, $\mathrm{Cr}$ (VI) is a genotoxic agent and associated the risk of lung cancer and other occupational diseases [15].

The DNA repair mechanisms are responsible for repairing the xenobiotic induced DNA damage and maintaining the genomic stability. DNA repair system is involved in the repair of $\mathrm{Cr}$ (VI)- induced DNA lesion such as Oxidative damage and single strand break, which are the main forms of DNA damage. Base excision repair (BER) pathway is mainly responsible for repair these DNA lesions. X-ray repair cross-complementing group 1 (XRCC1) is a key component in repairing both direct SSB and indirect SSB generated indirectly during base excision repair [20]. It serves as a scaffold connecting many of the other proteins involved in SSB repair. XRCC1 is recruited to SSBs by poly(ADP-ribose)polymerase (PARP1) and then interacts with a number of important proteins involved in SSB such as proliferating cell nuclear antigen (PCNA), DNA polymerase beta (Polb), and polynucleotide kinase (PNK) [20,21]. $\mathrm{XRCC1}$ was essential to reduce the formation of lead chromate induced chromatid lesions [22]. XRCC1 protein is involved in the repair of $\mathrm{Cr}(\mathrm{VI})$-induced SSB [23] and in protection from lead chromate-induced chromosome instability [22].

Genetic polymorphisms of key proteins might be involved in inter-individual variations of DNA repair processes and influence the extent of genotoxic damage. XRCC1 Arg399Gln, a functional genetic variation, may alter the capacity of XRCC1 to interact with several acting enzymes and associated with the efficiency of BER repair [24,25]. Many previous studies [26-28] revealed XRCC1 Arg399Gln was associated with the common cancers such as lung, bladder, esophageal cancers, etc. and modulated the cancer risk for common environmental exposure. In chromium-exposed electroplating workers, we found the polymorphism of XRCC1 Arg399Gln was associated the Olive tail moment, tail length and tail DNA\%. The subject carrying A allele reduced the risk of high DNA damage. In the previous studies, XRCC1 Arg399Gln was also found to be associated with chromosome aberrations [29] and micronuclei [18,30] in the chromium exposed welding worker. This polymorphism was also found to modulate the risk of DNA damage induced other occupational exposure to DNA damage agents such as vinyl chloride [31], asbestos [32] and 1,3-butadiene [33].

However, we didn't find significant association between XRCC1 Arg194Trp and the Cr (VI)-induced DNA damage. This finding was inconsistent with the previous studies [31,33]. We also failed to find any associations of the polymorphisms of ERCC1 C8092A, ERCC5 His1104Asp, ERCC6 Gly399Asp, GSTP1 Ile105Val, OGG1 Ser326Cys,
XPC Lys939Gln, XPD Lys751Gln with the DNA lesions. One of the possible reasons might be the specific effect of the DNA repair proteins responding to $\mathrm{Cr}$ (VI)-induced DNA damage. The other might be small sample size and relative low statistical power of test in this study. Only 122 chromium exposed electroplating workers were studied and false negative results might exist. Therefore, further study is required with large sample size and more statistical power to screen new genetic biomarkers of $\mathrm{Cr}(\mathrm{VI})$-induced DNA damage.

In conclusion, we found that the genetic variation of XRCC1 Arg399Gln was associated with the Cr (VI)-induced DNA damage. XRCC1 Arg399Gln may be served as a genetic marker of susceptibility and high risk individual identification for chromium exposed workers. With this genetic biomarker, the susceptible population could be screened and prevent from chromium exposure.

\section{Competing interests}

The authors declare that they have no competing interests.

\section{Authors' contributions}

$X Z$ participated in the epidemiological investigation, performed comet assay and ELISA, analyzed data and drafted the manuscript. X-HZ was a chief investigator and was responsible for the epidemiological design, and sample collection and drafting the manuscript. $\mathrm{X}-\mathrm{HZ}$ and $\mathrm{XZ}$ contributed equally to this work. LZ, Z-PY, HF, J-MY and QC carried out the health surveillance in the workplace and sample collection. Y-MZ participated in the overall design, study coordination, data analysis, and finalized the draft of the manuscript. All the authors read and approved the final manuscript.

\section{Acknowledgements}

This study was supported by Zhejiang Medical Health Science and Technology Foundation (2008B156) and by Key project of Medical Health Science and Technology Foundation (2008Z009). The authors are grateful to the collaborators in occupational surveillance, sample collection and epidemiological investigation: Jingmin Yu and Kangyi Zhong from Tonglu Centers for Disease Control and prevention (CDC); Weiguo Shou from Xiaoshan CDC; Hong Fu from Jiande CDC; Jinfang Sheng from Fuyang CDC.

\section{Author details}

${ }^{1}$ Department of Epidemiology and Biostatistics, Zhejiang University School of Medicine, 388 Yu-Hang-Tang Road, Hangzhou 310058, Zhejiang, People's Republic of China. ${ }^{2}$ Hangzhou Center for Disease Control and Prevention, Hangzhou 310021, People's Republic of China. 'Zhejiang Center for Disease Control and Prevention, Hangzhou 310051, People's Republic of China.

${ }^{4}$ Tonglu Center for Disease Control and prevention, Tonglu 311500, People's Republic of China. ${ }^{5}$ Jiande Center for Disease Control and prevention, Jiande 311600, People's Republic of China.

Received: 14 July 2011 Accepted: 15 May 2012

Published: 29 May 2012

\section{References}

1. Eastmond DA, Macgregor JT, Slesinski RS: Trivalent chromium: assessing the genotoxic risk of an essential trace element and widely used human and animal nutritional supplement. Crit Rev Toxicol 2008, 38(3):173-190.

2. Zhang $X H$, Zhang $X$, Wang $X C$, Jin $L F$, Yang $Z P$, Jiang $C X$, Chen $Q$, Ren $X B$, Cao JZ, Wang Q, et al: Chronic occupational exposure to hexavalent chromium causes DNA damage in electroplating workers. BMC Public Health 2011, 11(1):224.

3. Kuo HW, Chang SF, Wu KY, Wu FY: Chromium(VI) induced oxidative damage to DNA: increase of urinary 8-hydroxydeoxyguanosine concentrations (8-OHdG) among electroplating workers. Occupational and Environmental Medicine 2003, 60(8):590-594. 
4. Patlolla AK, Barnes C, Yedjou C, Velma VR, Tchounwou PB: Oxidative stress, DNA damage, and antioxidant enzyme activity induced by hexavalent chromium in Sprague-Dawley rats. Environ Toxicol 2009, 24(1):66-73.

5. Chiu A, Katz AJ, Beaubier J, Chiu N, Shi X: Genetic and cellular mechanisms in chromium and nickel carcinogenesis considering epidemiologic findings. Mol Cell Biochem 2004, 255(1-2):181-194.

6. Chiu A, Shi XL, Lee WK, Hill R, Wakeman TP, Katz A, Xu B, Dalal NS, Robertson JD, Chen C, et al: Review of chromium (VI) apoptosis, cellcycle-arrest, and carcinogenesis. J Environ Sci Health C Environ Carcinog Ecotoxicol Rev 2010, 28(3):188-230.

7. Davies JM, Easton DF, Bidstrup PL: Mortality from respiratory cancer and other causes in United Kingdom chromate production workers. $\mathrm{Br} J$ Ind Med 1991, 48(5):299-313.

8. De Flora S: Threshold mechanisms and site specificity in chromium(VI) carcinogenesis. Carcinogenesis 2000, 21(4):533-541.

9. IARC: Chromium, nickel and welding. IARC Monogr Eval Carcinog Risks Hum 1990, 49:1-648.

10. Nordberg J, Arner ES: Reactive oxygen species, antioxidants, and the mammalian thioredoxin system. Free Radic Biol Med 2001, 31(11): 1287-1312.

11. Wang $X F$, Xing $M L$, Shen $Y$, Zhu $X$, Xu LH: Oral administration of $\mathrm{Cr}(\mathrm{VI})$ induced oxidative stress, DNA damage and apoptotic cell death in mice. Toxicology 2006, 228(1):16-23.

12. Lee AJ, Hodges NJ, Chipman JK: Interindividual variability in response to sodium dichromate-induced oxidative DNA damage: role of the Ser326Cys polymorphism in the DNA-repair protein of 8-oxo-7,8dihydro-2'-deoxyguanosine DNA glycosylase 1. Cancer Epidemiol Biomarkers Prev 2005, 14(2):497-505.

13. Singh NP, McCoy MT, Tice RR, Schneider EL: A simple technique for quantitation of low levels of DNA damage in individual cells. Exp Cell Res 1988, 175(1):184-191.

14. Codd R, Dillon C, Levina A, Lay P: Studies on the genotoxicity of chromium: from the test tube to the cell. Coordination Chemistry Reviews 2001, 216:537-582.

15. Valko M, Morris $H$, Cronin M: Metals, toxicity and oxidative stress. Current Medicinal Chemistry 2005, 12(10):1161-1208.

16. Gao M, Binks S, Chipman J, Levy L, Braithwaite R, Brown S: Induction of DNA strand breaks in peripheral lymphocytes by soluble chromium compounds. Human \& Experimental Toxicology 1992, 11(2):77-82.

17. Macfie A, Hagan E, Zhitkovich A: Mechanism of DNA-Protein Cross-Linking by Chromium. Chemical Research in Toxicology 2010, 23(2):341-347.

18. larmarcovai G, Sari-Minodier I, Chaspoul F, Botta C, De Meo M, Orsiere T, Berge-Lefranc J, Gallice P, Botta A: Risk assessment of welders using analysis of eight metals by ICP-MS in blood and urine and DNA damage evaluation by the comet and micronucleus assays; influence of XRCC1 and XRCC3 polymorphisms. Mutagenesis 2005, 20(6):425-432.

19. Gambelunghe A, Piccinini R, Ambrogi M, Villarini M, Moretti M, Marchetti C, Abbritti G, Muzi G: Primary DNA damage in chrome-plating workers. Toxicology 2003, 188(2):187-195.

20. Caldecott KW: XRCC1 and DNA strand break repair. DNA Repair (Amst) 2003, 2(9):955-969.

21. Fan R, Kumaravel TS, Jalali F, Marrano P, Squire JA, Bristow RG: Defective DNA strand break repair after DNA damage in prostate cancer cells: implications for genetic instability and prostate cancer progression. Cancer Res 2004, 64(23):8526-8533.

22. Grlickova-Duzevik E, Wise SS, Munroe RC, Thompson WD, Wise JP: XRCC1 protects against particulate chromate-induced chromosome damage and cytotoxicity in Chinese hamster ovary cells. Toxicol Sci 2006, 92(2):409-415

23. Christie NT, Cantoni O, Evans RM, Meyn RE, Costa M: Use of mammalian DNA repair-deficient mutants to assess the effects of toxic metal compounds on DNA. Biochem Pharmacol 1984, 33(10):1661-1670.

24. Qu T, Morii E, Oboki K, Lu Y, Morimoto K: Micronuclei in EM9 cells expressing polymorphic forms of human XRCC1. Cancer Lett 2005, 221(1):91-95.

25. Marsin S, Vidal AE, Sossou M, Ménissier-de Murcia J, Le Page F, Boiteux S, de Murcia G, Radicella JP: Role of XRCC1 in the coordination and stimulation of oxidative DNA damage repair initiated by the DNA glycosylase hOGG1. J Biol Chem 2003, 278(45):44068-44074.

26. Kim IS, Lee GW, Kim DC, Kim HG, Kim S, Oh SY, Kim SH, Kwon HC: Polymorphisms and haplotypes in the XRCC1 gene and the risk of advanced non-small cell lung cancer. J Thorac Oncol 2010, 5(12): 1912-1921.

27. Hodgson ME, Poole C, Olshan AF, North KE, Zeng D, Millikan RC: Smoking and selected DNA repair gene polymorphisms in controls: systematic review and meta-analysis. Cancer Epidemiol Biomarkers Prev 2010, 19(12):3055-3086

28. Huang Y, Li L, Yu L: XRCC1 Arg399GIn, Arg194Trp and Arg280His polymorphisms in breast cancer risk: a meta-analysis. Mutagenesis 2009, 24(4):331-339.

29. Halasova E, Matakova T, Musak L, Polakova V, Letkova L, Dobrota D, Vodicka $P$ : Evaluating chromosomal damage in workers exposed to hexavalent chromium and the modulating role of polymorphisms of DNA repair genes. Int Arch Occup Environ Health 2011, doi:10.1007/s00420-011-0684-x.

30. larmarcovai G, Sari-Minodier I, Orsière T, De Méo M, Gallice P, Bideau C, Iniesta D, Pompili J, Bergé-Lefranc JL, Botta A: A combined analysis of XRCC1, XRCC3, GSTM1 and GSTT1 polymorphisms and centromere content of micronuclei in welders. Mutagenesis 2006, 21(2):159-165.

31. Qiu YL, Wang W, Wang T, Sun P, Wu F, Zhu SM, Qian J, Jin L, Au W, Xia ZL: DNA repair gene polymorphisms and micronucleus frequencies in Chinese workers exposed to vinyl chloride monomer. Int J Hyg Environ Health 2011, 214(3):225-230.

32. Zhao XH, Jia G, Liu YQ, Liu SW, Yan L, Jin Y, Liu N: Association between polymorphisms of DNA repair gene XRCC1 and DNA damage in asbestos-exposed workers. Biomed Environ Sci 2006, 19(3):232-238.

33. Wang Q, Wang AH, Tan HS, Feng NN, Ye YJ, Feng XQ, Liu G, Zheng YX, Xia ZL: Genetic polymorphisms of DNA repair genes and chromosomal damage in workers exposed to 1,3-butadiene. Carcinogenesis 2010, 31(5):858-863.

doi:10.1186/1756-0500-5-263

Cite this article as: Zhang et al.: XRCC1 Arg399GIn was associated with repair capacity for DNA damage induced by occupational chromium exposure. BMC Research Notes 2012 5:263

\section{Submit your next manuscript to BioMed Central and take full advantage of:}

- Convenient online submission

- Thorough peer review

- No space constraints or color figure charges

- Immediate publication on acceptance

- Inclusion in PubMed, CAS, Scopus and Google Scholar

- Research which is freely available for redistribution

Submit your manuscript at www.biomedcentral.com/submit
C) Biomed Central 